\title{
Profile of public relations practitioners in Poland: Research results
}

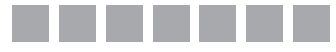 \\ Dariusz Tworzydło \\ ORCID: 0000-0001-6396-6927
}

UNIVERSITY OF WARSAW, POLAND

Przemysław Szuba

ORCID: 0000-0002-7533-7818

EXACTO SP. 2 O.O., POLAND

Norbert Życzyński

ORCID: 0000-0003-0681-3072

COMMIT POLAND SP. Z O.O., POLAND

DOI: 10.19195/1899-5101.12.3(24).5

\begin{abstract}
The article is a summary of three quantitative research projects carried out in the years 2017-2018 taking into account a set of analogous questions. Their collective aggregation allows the attempt to present the profile of a Polish PR specialist with the indication of the main activities undertaken while performing daily professional duties. The research has shown that media relations and e-PR play a key role in everyday professional work. Nevertheless, a PR specialist in Poland has to deal with many task areas, which are often related to the dynamic development of new technologies, such as relations with influencers. In the analyses, the key diagnostic element was the measurement of professional experience and information regarding employment aspects. Respondents constituted both specialists working in PR agencies as well as in other domestic companies and institutions. The article contains a list of activities presented in statistical terms that are related to work in the PR industry.
\end{abstract}

KEYWORDS: PR specialist, public relations, task areas, professional work, research, public relations agencies.

\section{INTRODUCTION}

Dynamic changes taking place in the market of public relations (PR) services strongly affect the scope of PR specialists' responsibilities, who must possess a wide and 
constantly increasing range of competencies regarding communication processes. This applies not only to knowledge but also to experience. Professional competencies also constitute a highly significant element, as the development of technology enforces specialization in many areas of PR. When carrying out multifaceted projects that are often based on a conglomerate of techniques and tools used in PR, PR specialist professional work nowadays boils down to the role of a polymath. The important element is not only the specialization in social media support combined with message processing, but also planned and long-term strategic actions, which aim at creation or maintenance of a favorable public image (Executive Office of the President Office of Management and Budget, 2018, pp. 32, 97).

The subject of the article is the analysis of issues related to the performance of professional duties of PR specialists, which in a simplified manner is connected with building reliable relations with the environment. The authors, using quantitative research, made an attempt to find an answer to the question: What are the main tasks of PR specialists when performing their daily professional duties in Poland?

The Public Relations Lexicon defines the PR specialist as a person employed in an agency, company or organization on a full-time basis, on a contract to perform a specific task or contract of commission. Therefore such a definition was adopted in the analysis of the research results contained in this article. A PR specialist performs a number of tasks included in the scope of PR activities while complying with certain ethical principles and standards, e.g., codes of industry organizations (Olędzki \& Tworzydło, 2009, p. 138). The main objectives of the PR practitioner are to take care of relations with the strategic environment and to provide the information expected by the environment along with explaining the activities of the organization for which the PR specialist works (Olędzki, Wojcik, Hope, \& Barlik, 2019, p. 13).

Andrzej Godewski (2011, p. 341) points out that work in PR departments is very often associated with a large number of activities conducted with limited resources. In addition to staff shortages, many companies wrestle with a problem regarding the proper management of activities conducted in PR spheres, which results from limited competencies. That is why sometimes the quickest and the most professional help can be obtained by employing a specialist firm in which PR specialists play a leading role. Of course, also advantages, as well as disadvantages related to the implementation of PR activities with the cooperation of PR agencies, can be indicated. The rapidity of actions mentioned above may be limited if the specificity of the company for which the agency works and its organizational structure is complicated and takes a long time to comprehend. However, this aspect is just one of many factors determining the final choice and decision regarding the fact whether PR activities should be carried out independently (by the company and its team) or outsourced or whether a combination of these solutions should be used.

Specialists and experts representing the PR industry very often, in addition to actions typically identified with PR, undertake activities that are excluded from the PR task areas, such as CSR. The article identifies the problems regarding the interpretation 
of terms and the variety of tasks that respondents who operate in the PR industry deal with. Research projects that formed the basis for the creation of this article give a general picture of the environment and show how extensive the knowledge and experience of people who deal with communication and relationship building must be. They also show how important are self-improvement and development, which constitutes a prerequisite for success that a person managing with the scope of PR activities can potentially obtain.

The article is also a set of analyses showing how extensive and diverse is the scope of tasks that representatives of the PR industry in Poland deal with. Its purpose is to determine the main components of the PR practitioner profile. The article also indicates the main task areas, including the assessment of the area of changes that may and will be made due to technological development as well as the development of tools used in communication.

\section{THE RESEARCH MODEL AND CHARACTERISTICS OF THE SURVEYED PR SPECIALISTS}

In 2017-2018, three independent research projects were carried out, ${ }^{1}$ the aim of which was to gather the opinions of representatives of the Polish PR community in the context of current trends and the functioning of the industry. The combination of data from several surveys conducted in a relatively short period of time made it possible to broaden the research sample and conduct analyses among a larger number of PR specialists. However, this approach resulted in the probe being dominated by representatives of $\mathrm{PR}$ agencies due to the dedicated nature of the third research project. Nevertheless, getting to know their opinions is extremely important in the context of drawing conclusions about the type of professional duties they perform. In addition, each of the projects covered the PR specialists who represented both PR agencies, companies and public sector institutions. This state of affairs allowed the collection of data obtained from a wide range of respondents who jointly participate in the development of the PR industry in Poland. The research was conducted during the leading event integrating the PR sector in Poland, i.e., the PR Professionals Congress (purposive sampling) and a telephone survey among PR agencies in Poland (the sampling frame constituted a database of 736 entities with registered activity).

The structure of applied research tools (CATI, CAWI and PAPI questionnaires) enabled an analysis of the respondents' professional work, their specificity and the

1 First project: "Analysis of the condition of the public relations industry” (Rzeszów 2017) - auditory survey of the participants the of PR Professionals Congress. Completion date April 20-21, 2017. Second project: "Oppressiveness of the industry" (Rzeszów 2018) - survey of the participants of the PR Professionals Congress supported by CAWI research conducted after the end of the event to broaden the research sample. Completion date April 19-30, 2018. Third project: "Public relations of crisis from the perspective of PR agencies" - analysis of trends and conditions (Rzeszów, Warsaw 2018) - CATI research among Polish PR agencies. Completion date March-June 2018. 
frequency of execution of specific types of tasks. Each questionnaire contained a common part that enabled the design of a collective model based on unique information. This implies that for the purposes of the analysis, duplicates were rejected, the presence of which resulted from the combination of three different sets of data into one collective matrix. For instance, a duplicate was considered a situation where the agency/company/ institution participated in at least two research tasks. In such cases, only the most up-to-date data were analyzed. After the verification of the logical coherence of the matrix, statistical calculations were carried out based on 494 interviews with people working in the PR industry (PR specialists). The common denominator of the research sample obtained in this manner constituted information that could be presented using the following set of thematic indicators:

— total number of years of work in the PR industry (quantitative measurement),

- position held in the organization (executive, executive-management, and managing),

- represented entity (PR agency, the company — private sector, institution public sector),

— professional work (in a PR agency or outside of the agency),

- activity undertaken in selected task areas as part of daily professional duties (multiple answers),

- defining oppressive industries, i.e., particularly vulnerable to the occurrence of crisis situations (association test). ${ }^{2}$

Frequency distributions and participation variables are presented in Table 1.

Respondents are mainly representatives of the management departments of their organizations, i.e., decision-makers influencing the shape of strategic dimensions in a company or institution, including owners, presidents, board members, senior managers. In total, they constitute over $2 / 5$ of the respondents. On average, every third respondent assigned his position to the mixed model of the position held (35.1\%). This means that during the performance of professional duties there is an alternate implementation of operational and management tasks. On the other hand, $22.5 \%$ of the respondents were people working in strictly executive positions, e.g., specialists or lower-level management.

The vast majority of surveyed PR specialists work in PR agencies (54.5\%). The second largest group in terms of size were representatives of the private sector (28.2\%), while those dealing with PR in public institutions constituted relatively the smallest group in the research sample $-17.3 \%$. The "Work in the industry" variable was also prepared for analysis, which diversifies the respondents to those who work in the PR agency (54.5\%) and other PR specialists (45.5\%). Proportional distribution of this variable will enable the conducting of more meaningful analyses and comparisons.

2 The aspect of crisis vulnerability will not be discussed in this article because of the narrative conducted only in the area of diagnosis of the profile of people working in the PR sector in Poland. 
Table 1. Profile of the surveyed PR specialists - sampling $(N=494)$

\begin{tabular}{|c|c|c|c|c|c|c|c|c|}
\hline \multirow[b]{2}{*}{$\begin{array}{l}\text { Frequency } \\
\text { distribution }\end{array}$} & \multicolumn{3}{|c|}{ Position held } & \multicolumn{3}{|c|}{ Represented entity } & \multicolumn{2}{|c|}{$\begin{array}{c}\text { Work } \\
\text { in the industry }\end{array}$} \\
\hline & 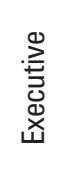 & 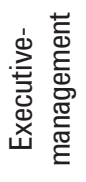 & 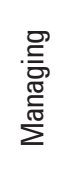 & 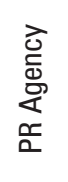 & 站 & 胥 & 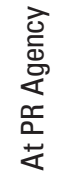 & $\begin{array}{l}\bar{\Phi} \\
\stackrel{ \pm}{ \pm}\end{array}$ \\
\hline $\begin{array}{l}\text { Number of } \\
\text { responses }(N)\end{array}$ & 109 & 170 & 206 & 261 & 135 & 83 & 261 & 218 \\
\hline Percentage (\%) & 22.5 & 35.1 & 42.5 & 54.5 & 28.2 & 17.3 & 54.5 & 45.5 \\
\hline Base & \multicolumn{3}{|c|}{485} & \multicolumn{3}{|c|}{479} & \multicolumn{2}{|c|}{479} \\
\hline Data shortages & \multicolumn{3}{|c|}{9} & \multicolumn{3}{|c|}{15} & \multicolumn{2}{|c|}{15} \\
\hline
\end{tabular}

Source: Authors.

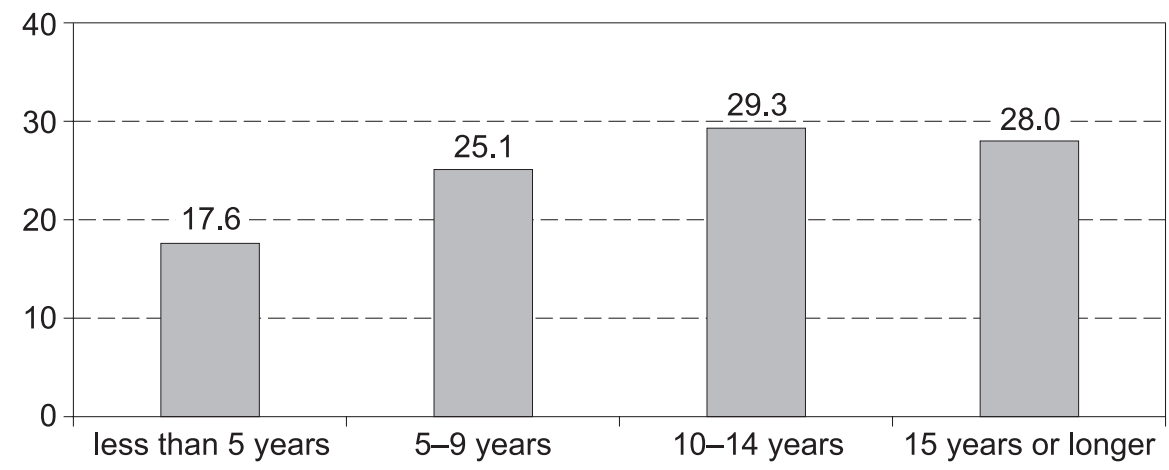

Figure 1. Professional experience, i.e., the total number of years of work in the PR industry, $N=471$ (in \%). Statistics: $M=10.63 ; M e=10.00 ; S D=6.198$; $\operatorname{Min}=0 ; \operatorname{Max}=30$.

Source: Authors.

The statistical PR specialist surveyed can boast about the professional experience at the level of almost 11 years of work experience in the PR industry (Figure 1). The most numerous group were people from the range of 10 to 14 years of work experience $-29.3 \%$. A slightly smaller percentage of people $(28 \%)$ declared that they have been working in the industry for at least 15 years. One in four PR specialists was classified in the range of 5-9 years of work experience, while less than $18 \%$ do not have 5 years job seniority in the PR industry. Bearing in mind that the beginnings of the PR industry in Poland occurred in the early 1990s, it can be pointed out that the research sample included leading professionals working on the domestic PR market. Suffice it to say that $12.7 \%$ of respondents (i.e., 60 people) have worked in the PR industry for a minimum of 20 years. 
The measurement of professional experience is a key diagnostic element when trying to develop an image of a Polish PR specialist. This was confirmed by the analysis of comparisons of averages and statistical tests, which showed significant variation. Based on these calculations, it can be observed that the structure of the positions held depends to a large extent on the length of job seniority, because the average number of years worked in the industry regarding a managing position is almost 13 years. Among people located at the lower levels of the organizational structure, the abovementioned indicator was relatively lower, i.e., 10 and a half years of work experience at executive-management positions, and slightly over 6 years at executive positions. Post hoc tests showed significant differences in each of the three test variants of the categorical variable "Position" ( $p<0.001)$, i.e., executive vs. executive-management (difference of averages -4.22 ), executive vs. managing (difference of averages -6.63) and executive-management vs. managing (difference of averages -2.41) (Table 2).

Table 2. PR specialist profile with respect to professional experience (average number of years of work in the PR industry)

\begin{tabular}{|c|c|c|c|}
\hline \multicolumn{2}{|c|}{} & \multicolumn{2}{|c|}{ Experience } \\
\cline { 3 - 4 } \multicolumn{2}{|c|}{ Categories } & $N$ & $\begin{array}{c}\text { Years in the PR } \\
\text { industry }(M)\end{array}$ \\
\hline \multirow{3}{*}{ Position $^{*}$} & Executive & 100 & 6.33 \\
\cline { 2 - 4 } & Executive-management & 163 & 10.55 \\
\cline { 2 - 4 } & Managing & 201 & $\mathbf{1 2 . 9 6}$ \\
\hline \multirow{3}{*}{ Entity } & PR Agency & 257 & $\mathbf{1 1 . 9 9}$ \\
\cline { 2 - 4 } & Firm & 126 & 9.19 \\
\hline \multirow{3}{*}{ Work $^{* * *}$} & Institution & 81 & 8.81 \\
\cline { 2 - 4 } & At a PR Agency & 257 & $\mathbf{1 1 . 9 9}$ \\
\cline { 2 - 4 } & Other places of employment & 207 & 9.04 \\
\hline
\end{tabular}

Note: ${ }^{\star}$ Kruskal Wallis Test: $H=79.691 ; d f=2 ; p<0.001 ;{ }^{\star \star}$ Kruskal Wallis Test: $H=29.285 ; d f=2 ; p<0.001$; ${ }^{\star * \star}$ Mann-Whitney Test: $U=18875 ; Z=(-5.393) ; p<0.001$.

Source: Authors.

Looking through the prism of the represented entity, one can see a significant advantage of the experience of PR specialists employed in PR agencies $(M=11.99)$, in relation to their colleagues from the public sector $(M=9.19)$ and specialists representing external companies $(M=8.81)$. People employed in agencies have on average three years longer work experience in the industry. However, the difference between the experience of companies and institutions was statistically insignificant, as demonstrated by Bonferroni's post-hoc test. On the other hand, by comparing the agency's 
employees with other PR specialists, one can clearly see the advantage of the first group in terms of the time of work in the PR industry. Therefore, it is legitimate to advocate greater professional experience of PR agency employees.

\section{THE PR SPECIALIST PROFESSION IN THE CROSS-SECTION OF TASK AREAS}

Development of effective communication strategies by PR specialists requires expert knowledge in many thematic areas. In the PR industry, there are several key areas, which in the literature of the subject are called task spheres. They are "permanent, almost invariable elements, described by general and specific purposes. While their implementation, tools (instruments) are used and they are variable, adapted to the situation or program and depend on what, for example, the development of technologies and information systems gives." (Tworzydło, 2017, p. 41). PR task areas (Figure 2) constitute primarily internal communication, crisis management, media relations, investor relations and relations with other groups of the external environment (sponsorship, public affairs, lobbying, relations with local communities, CSR) (Tworzydło, 2017, pp. 40-41).

In our research, the character of responses was semi-open with the possibility of multiple choice answers, so that respondents could indicate the main areas of their professional work. Therefore, those studies provide a broader portrayal of the understanding of individual areas that PR practitioners deal with and show the diversity of approaches to the nomenclature and the tasks they carry out. In the research process, an important element taken into account was the nature of professional duties.

In the course of analytical work, 15 categories to which respondents were assigned were identified. Nearly three-quarters of those specialists surveyed focus onmedia relations during their daily duties. While analyzing this area as the main one indicated by the respondents, it should be noted that according to the typology of Macnamara, organizations use the mass media to support internal communication processes (inbound messages/internal communication) and reach the external environment (outbound messages/external communication). Typical interactions with the mass media related to internal communication include sourcing content for internal news services, monitoring media and public opinion, including evaluation of the media coverage of the organization, its products or services and evaluation of the relationship between media representatives and organization. On the other hand, the key outbound practices are: spreading information about the organization, its products or services, producing high-quality content and/or creation of topical platforms (Zerfass, Verčič, \& Wiesenberg, 2016). The media relations specialists' aim is to send information to the media and invite the media to see the company's operations first-hand. However, this sphere of PR is not necessarily the best method of obtaining public recognition. Patterson (1999) argues that today's main PR challenge "isn't getting noticed, it's getting believed and trusted." And this aspect related to obtaining trust should be a key component of activities undertaken within PR. 


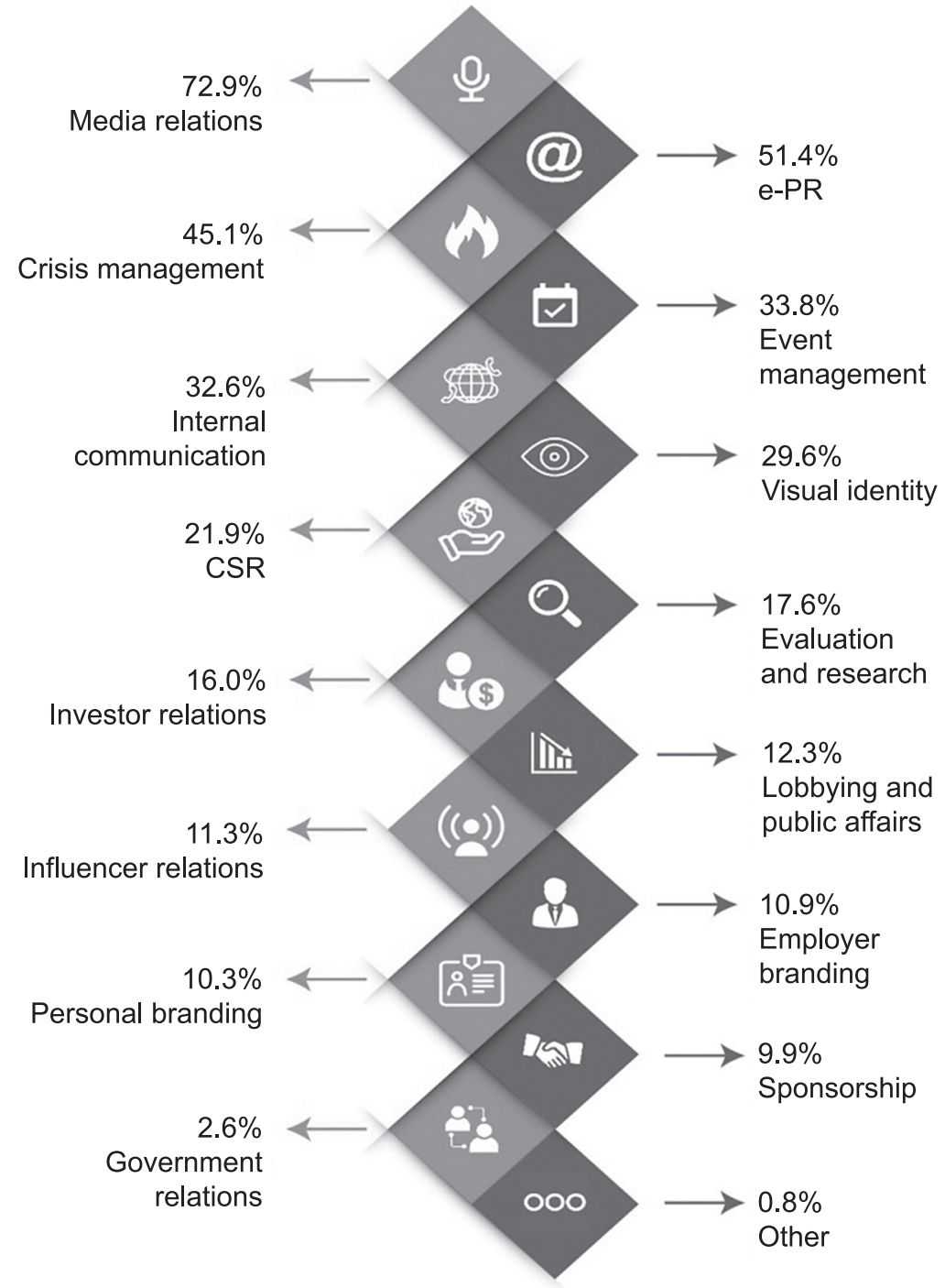

Figure 2. Professional work of a PR specialist (analysis of multiple responses) ${ }^{3}$

Source: Authors.

In addition to maintaining proper relations with the media, only one sphere has obtained more than half of the possible indications - a platform for creating the image in the network (51.4\%). Digital PR, sometimes referred to as online PR

3 Content of the question: "In the course of my daily professional duties, I undertake relatively most of PR-related activities regarding...”; a total of 494 surveyed PR specialists generated 1,873 important observations in terms of multiple answers. 
or e-PR, includes the publication of online news releases to inform stakeholders about the services or activities of the organization, using the power of networks, including journalists, to disseminate information through the Internet (Gifford, 2010, pp. 62-72). Year-on-year, activities undertaken on the Internet are increasingly determining the overall activity of people working in the PR industry.

Crisis communication, the organization of events and internal PR are also important elements of PR activities. The first of these three elements mentioned above - crisis management - is a specific task sphere of PR due to its permeation of all other spheres. For instance, crises are very often associated with media relations, especially those crises that burgeon and go beyond the walls of the organization. The same applies to the relationship between crisis management and internal relations. Problematic situations are a constant element accompanying activities related to internal PR. Procedures, tasks and issues related to responses are just as connected with media relations as with the organization's inner life. The crises are also closely related to the public affairs area because it is natural that relations with local communities generate conflict situations and contentious issues, which may translate into more severe image-related problems.

Respondents indicate that their tasks also include work connected with visual identification (29.6\%) and corporate social responsibility (CSR) (21.9\%). All the remaining answers were given relatively less frequently, which may result from the specificity of these certain activities or simply other needs of entities for which the specialist or expert performs specific actions classified within the field of PR task areas. The less popular activities include government relations (2.6\%) and sponsorship (9.9\%). It is worth noting that the concepts of public affairs and government relations are identified and treated as one broad area. However, they also happen to be treated as separate beings, with government relations being a narrower concept that illustrates relations mainly with governmental environments, while public affairs cover the sphere of relations existing between the government, politics and opinion-forming circles in the context of shaping the expected image in the environment. In both cases, first of all, it is essential to realize that knowledge of the regulatory environment and the support of decision-makers shapes the socio-economic reality, which ultimately becomes a prerequisite for the successful implementation of important social and business projects (Fleishman Hillard, 2019). Some agencies implement public affairs activities as well as governmental affairs, treating them as separate beings, while others focus only on the first or second task area, indicating it as the main direction of their action. In the case of public affairs, such activities are design and implementation of campaigns, including educational campaigns, analysis and monitoring of changes in the field of implementation of legislation in specific sectors of the economy, community involvement in decision making and influencing those decisions in the context of decisions recommended by specific entities interested, negotiations and others. It should be noted that, as indicated by the PR practitioners surveyed, for these two areas the greater experience is required. 
While analyzing the results of the research, it is important to underline the fact that on average, every tenth respondent indicated building a personal brand or employer branding. In the surveyed sample, the statistical PR specialist showed four different areas of their professional work $(M=3.79)$. Interesting is also the fact that the more years of work in the industry, the more extensive the range of PR activities undertaken is (Spearman's rank correlation coefficient: $r h o=0.097 ; p=0.035 ; n=471$ ). Therefore, whether the distribution of professional experience is proportional in individual spheres, or whether there are areas in which the seniority significantly exceeds the average for the sample $(M=10.63)$ requires verification (Table 3$)$.

Table 3. Comparison between average seniority of PR employees and activity undertaken in task areas ${ }^{4}$

\begin{tabular}{|c|c|c|c|c|}
\hline \multirow[b]{2}{*}{ No } & \multirow{2}{*}{$\begin{array}{c}\text { Task areas in which PR specialists } \\
\text { are active }\end{array}$} & \multicolumn{2}{|c|}{ Experience } & \multirow{2}{*}{$\begin{array}{l}\text { Loss on points } \\
\text { regarding the } \\
\text { leader }\end{array}$} \\
\hline & & $N$ & $\begin{array}{l}\text { Years in the PR } \\
\text { industry }(M)\end{array}$ & \\
\hline 1. & Lobbying and public affairs & 56 & 13.45 & \\
\hline 2. & Government relations & 12 & 12.00 & -1.45 \\
\hline 3. & Employer branding & 53 & 11.87 & -1.58 \\
\hline 4. & Crisis management & 208 & 11.64 & -1.81 \\
\hline 5. & Evaluation and research & 79 & 11.58 & -1.86 \\
\hline 6. & Influencer relations & 55 & 11.44 & -2.01 \\
\hline 7. & Personal branding & 49 & 11.02 & -2.43 \\
\hline 8. & Media relations & 345 & 10.99 & -2.45 \\
\hline 9. & Sponsorship & 45 & 10.62 & -2.82 \\
\hline 10. & Internal communication & 153 & 10.52 & -2.93 \\
\hline 11. & CSR & 101 & 10.35 & -3.10 \\
\hline 12. & e-PR & 240 & 10.13 & -3.32 \\
\hline 13. & Investor relations & 69 & 10.03 & -3.42 \\
\hline 14. & Event management & 158 & 9.57 & -3.88 \\
\hline 15. & Visual identity & 135 & 9.20 & -4.25 \\
\hline
\end{tabular}

Source: Authors.

4 The analysis takes into account only persons who declared the implementation of activities in the tested task areas (answer "Yes") and provided the total number of years of work in the PR industry. 
Looking through the prism of the expanding range of tasks performed by PR practitioners and the increase in a number of those tasks, a thesis advocating the very broad range of activities that must be carried out by PR specialists and experts as part of their daily work is confirmed. Thus, more and more specific competencies and knowledge, that can be used in daily work, are required even from PR adepts employed in companies, organizations or agencies. However, in a study devoted to the analysis of the condition of the PR industry in Poland, as many as $22 \%$ of the surveyed PR specialists notice the recruitment difficulties associated with finding good PR specialists. In connection with the above, they assessed the level of the availability of professional staff on the market in a pejorative manner (Tworzydło, Szuba, \& Zajic, 2017, pp. 36-39).

The analysis of data obtained through research reveals a portrayal of two spheres in which relatively large professional experience is required (index of years worked in the industry), which is associated with sensitivity and intuition in conducting communication processes and planning strategic activities of the organization. These two spheres are lobbying and maintaining relationships with the government. This is due to the complexity of the activities in these areas, which must be supported by knowledge, experience, and broad business contacts. Similar patterns are observed by Thomlinson, who in her research searched for factors determining the scope of professional duties of PR specialists (Thomlinson, 2016, pp. 154, 163). Specialists responsible for building the employer branding, PR crisis management and measuring the effects of PR activities, are also placed high in the above ranking (places 3-5).

Based on the data, it can be concluded that the tasks related to the graphic designing of the brand image and the organization of events should be classified in the category where the basic tools of PR are used. This is confirmed by a low rate of professional experience, which indicates how much experience you need in order to implement such tasks. It is worth noting that the difference between the aspect placed in first place in the above rankings and the aspect located in last place exceeds the period of four years of work experience in the industry.

At this point, the differences that occur in professional work activities within the group represented by the surveyed respondents should also be indicated. Specialists working in PR agencies significantly more frequently in relation to the rest of the sample carry out tasks related to media relations ( $78.5 \%$ vs. $65.6 \%)$, lobbying and public affairs (14.6\% vs. $7.8 \%)$ and undertake cooperation with influencers $(19.5 \%$ vs. 2.3\%). On the other hand, respondents employed in companies other than PR agencies declared a greater focus on crisis management ( $51.4 \%$ vs. $38.7 \%)$, internal communication ( $37.2 \%$ vs. $27.6 \%$ ), investor relations ( $19.3 \%$ vs. $9.6 \%$ ), and CSR $(25.7 \%$ vs. $16.5 \%)$. Especially this subject, namely CSR, requires broadening. It is worth pointing out that the correlation between PR and CSR is the main theme of discussion in many environments. Some experts and PR specialists incorporate CSR into the set of PR task areas. Sometimes they do this unconsciously, without taking into account that CSR assumes undertaking virtuous actions, without the 


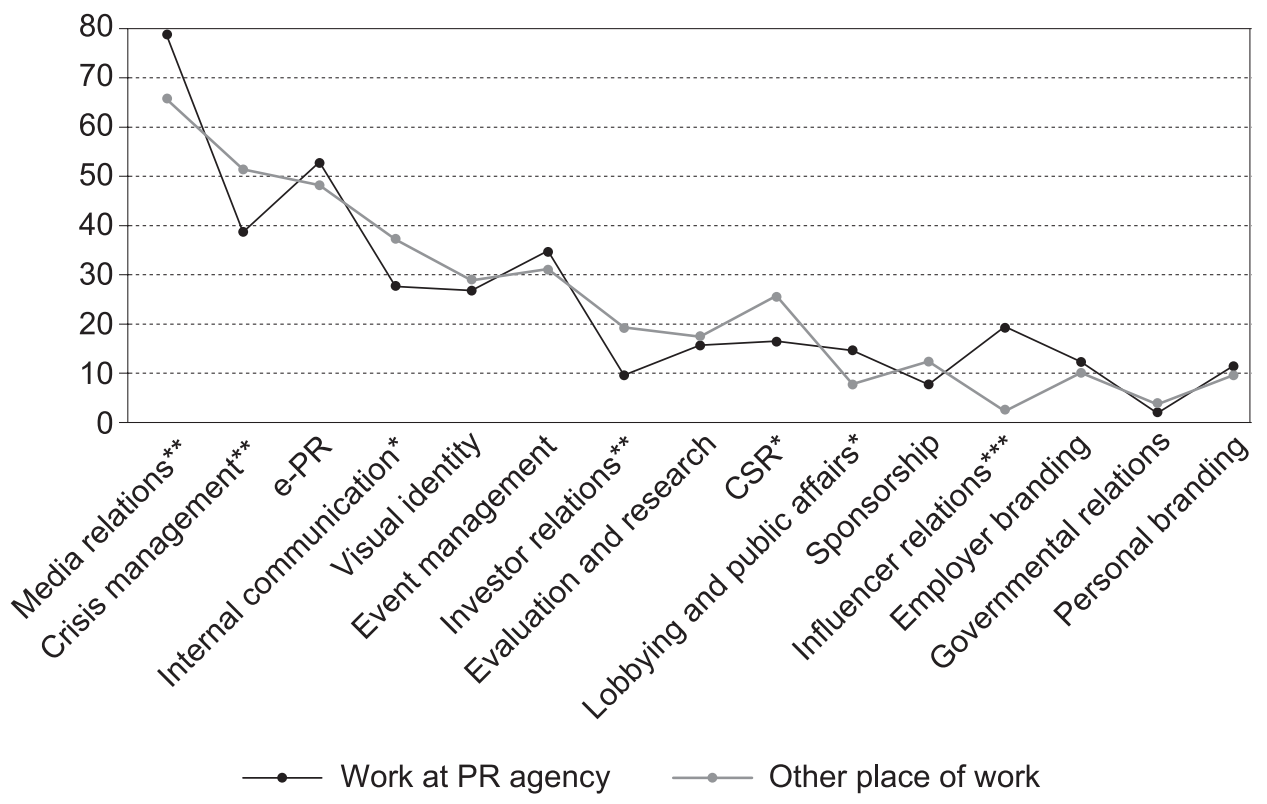

Figure 3. Activity in task areas in relation to the work performed (in \%)

Note: Chi-square independence test: ${ }^{*} p<0.05 ;{ }^{* *} p<0.01 ;{ }^{* *} p<0.001$.

Source: Authors.

expectation of strengthening the reception and building one's image, as in the case of PR (Chatterjee, 2017). Nevertheless, even without considering CSR as a PR task area, the result of building relations with the environment regarding taking socially responsible actions is unconsciously obtained.

The distribution of responses in the sphere of PR crisis management is particularly engaging. Greater activity of the "non-agency-employed" PR specialist may indicate that organizations are first trying to solve image problems (based on the competencies of internal PR resources), and only later do they turn to specialized entities for help. The tasks of anti-crisis departments in companies are to undertake security and responding actions on an ongoing basis, even when the crisis is only being during evaluation. PR agencies are most often employed in a situation when the crisis will actually take place. ${ }^{5}$

It is worth mentioning that sometimes the decision to implement an external rescue system is made too late, and thus the chances of reducing the scale of the negative effects of the crisis are diminishing. This fact is confirmed by research conducted among Polish PR agencies, where respondents were leaders

5 The analysis takes into account only persons who declared the implementation of activities in the tested task areas (answer "Yes") and provided the total number of years of work in the PR industry. 
and managers responsible for the implementation of contracts with trade partners. The observations made by them show that clients use crisis management services only when it is necessary to manage the existing crisis and to ensure its ending. Some $44 \%$ of respondents indicated cooperation based on ad hoc solutions. An unfavorable phenomenon is also the fact that every third respondent (32\%) expressed his conviction that the security system is being developed by the agency's clients only under the influence of the negative effects of the already experienced crises. The idea of preparation or conscious approach to the crisis only when it actually takes place is unfavorable from the point of view of the stable operation of business entities. It is much more appropriate to be prepared for the emergence of image crises, just because of the fact that the consequences of a crisis situation, when the company is prepared for it, can be significantly limited. The negative image is intensified by the indicator being on the level of only 7\%, which informs about conscious preventive actions. This is definitely too small a percentage of clients who want to cooperate with the agency to adequately prepare themselves for the risk of image perturbation and try to strengthen their prevention system, acting in accordance with the principle that prevention is better than cure. The analysis of trends related to the period of cooperation established with a PR agency is complemented by the $17 \%$ of respondents who, based on the concluded agreements and their own experiences, are unable to identify a common denominator in the activities of companies seeking crisis support (Tworzydło \& Szuba, forthcoming).

Correlation analyses between activity in the 15 tested task areas (dichotomous coding $0-$ lack or $1-$ activity) and the position held in the organization ( 1 - executive, $2-$ mixed, 3 - managing), showed dependencies only in three thematic areas. The relationship was measured using Kendall's Tau test for ordinal variables, which informs about the monotonic relationship between variables. The coefficient assumes values from -1 to +1 , and significant results in the sample at the level of $p<0.05$ should be interpreted as follows:

- the higher position in the organizational structure the PR specialist occupies, the less frequently actions related to the organization of events in his/her organization are taken (Kendall's tau correlation coefficient: $r=(-0.121) ; p=0.005 ; n=485)$, such tasks are attributed to people in operational positions;

- a higher position determines the intensification of lobbying and public affairs activities, which may result from the difficult scope of issues and requirements for people dealing with the above-mentioned;

- representatives of managerial positions more often declared that they establish relationships with influencers as part of their daily professional duties (Kendall's tau correlation coefficient: $r=0.091 ; p=0.035 ; n=485$ ).

In the course of the analyses, the influence of job seniority influencing the activity in individual task areas was also observed. Overall, the better the professional experience of the PR specialist (the number of years worked in the industry), 
the greater his/her activity in the field of media relations, crisis communication, and lobbying activities (Kendall's tau correlation coefficient: $r=0.154 ; p=0.001$; $n=471$ ). However, the reverse dependence occurred in the sphere of visual (Kendall's tau correlation coefficient: $r=(-0.123) ; p=0.001 ; n=471)$ and event identification (Kendall's tau correlation coefficient: $r=(-0.106) ; p=0.006 ; n=471$ ), i.e., through the increase in experience, professional activity decreased in these two areas of PR.

\section{CONCLUSIONS}

The conducted research showed that work in the PR sector is closely related to the ability to find oneself in different environments, along with adapting to changing circumstances and the subject matter of the projects being implemented. PR professionals' daily job duties are often a conglomerate of many task areas. They are implemented using many tools. Suffice it to say that only $5.5 \%$ of respondents declared that relatively most activities related to PR are undertaken within only one task area. Thus, unidirectional activity is a marginal phenomenon in this profession, since the majority of respondents' answers were of a multiple nature (mean 3.79, median 4 ). The diversity of tasks of PR specialists is also indicated by data of the European Association of Communication Directors (EACD). The report testing the role model showed that marketing and PR specialists from Western European countries (Austria, Belgium, France, Germany, Luxembourg, Netherlands, Switzerland, and the United Kingdom) have different roles that are rooted in the nature of their professions. The researchers distinguished four key groups of classification, i.e. diagnosis, coaching, liaison, and execution (Fieseler, Lutz, \& Meckel, 2015, pp. 6-9).

An image of the PR specialist emerges from the research, and in a simplified way can be described as a person responsible for maintaining proper relations with the media, creating the image of the organization using tools available on the Internet and conducting activities related to the preparation and management of communication in crisis situations.

The analysis of professional duties in terms of the place of employment (PR agency, company or institution) showed significant differences in the case of seven task areas. In the group of PR agencies, there has been recorded a relatively highest percentage of indications for media relations $-78.5 \%$, lobbying and public affairs $-14.6 \%$, and for relations with influencers $-19.5 \%$. On the other hand, the segment of companies more often pointed to crisis management $(52.6 \%)$, internal communication - 45.2\%, investor relations (22.2\%) and CSR (30.4\%). Specialists responsible for PR activities employed in institutions are practically not involved in lobbying activities (2.4\% of answers "Yes") and in relations with influencers $(1.2 \%)$. 
Research has shown that the group of particularly demanding areas includes crisis management, public affairs, and lobbying. However, as in the first case, potential crises, as well as their actual influence on companies, mean that skills of the PR specialist are often acquired during problem-solving, the second case consists of areas that require not only experience and knowledge but also an in-depth understanding of the subject. "Lobbying is a profession full of people who have changed careers, since relevant knowledge and experience are all you really need to become a lobbyist" (The Princeton Review, n.d., n.p.).

Conducting diagnostic tests among PR specialists is an important educational and analytical aspect of the development of PR in Poland. Such initiatives gain particular significance in connection with the progressing process of declining public trust in the PR industry (the belief that "PR has bad PR"). One should also remember about the problems related to the very understanding of the scope of PR activities, which are intensified by numerous media messages, where the term public relations occurs mainly in the context of the image (Przybysz, 2017, p. 21). Data obtained from the Institute of Media Monitoring ${ }^{6}$ shows that the usage of the term "public relations" and the abbreviation "PR" in the context of unethical communication techniques is becoming an increasingly common phenomenon in the Polish public debate. The subject area related to PR appears mainly in reference to politics (54\%) and interrelated aspects of business, economics, marketing, and finance (17\%). Only $11 \%$ constituted materials related to PR as a profession, the work of specialists and the PR industry (i.e., the classic elements of the field that is part of the communication services sector).The remaining references were indexed to the following categories: society $-9 \%$, sport $-4 \%$, celebrities and rumors $2 \%$, others $-3 \%$ (Związek Firm Public Relations, 2019). Taking into account the pejorative media image and the average condition of the PR industry, it is worth considering undertaking the next research, for which the analyses presented in this article may be a basis.

Here, it is also worth pointing out that one of the key components of the profile of a PR specialist employed in a company in a PR agency is experience. Experience is a particularly important condition for practitioners willing to take up difficult challenges. This is, of course, a logical conclusion, which shows how significant constant improvement and expanding one's skills are. Being an expert requires extensive knowledge, including specialization in several independent fields. Law, economics, sociology, psychology are only selected sciences and areas of practical engagement, in the framework of which the PR practitioner needs to improve in order to eventually become an expert being able to get to a higher level of strategic commitment regarding advising management of companies and institutions.

${ }^{6}$ From May 1 to October 31, 2018, Polish media published 3,177 materials with thematic slogans related to widely understood $\mathrm{PR}$. 
The above-mentioned interdisciplinary nature requires people who develop in the industry, not only self-improvement, extending skills, but also a broad general social view and knowledge. The research shows that employees of PR agencies are characterized by greater experience and its diversification. Such a conclusion allows us to go further and point out that experience in many different fields can have both a positive and negative impact on the quality of consulting provided to clients. We must not forget that in this situation we can observe a problem resulting from extensive knowledge in various areas and limited knowledge in one specific field of specialization, which is sometimes required, especially in difficult management issues.

\section{REFERENCES}

Chatterjee, P. (2017). CSR is not PR, you do good because you want to do good. Retrieved February 16, 2019, from http://www.forbesindia.com/article/special/csr-is-not-pr-you-do-good-because-youwant-to-do-good/46083/1.

Executive Office of the President Office of Management and Budget. (2018). Standard Occupational Classification Manual. Retrieved February 16, 2019, from https://www.bls.gov/soc/2018/ soc_2018_manual.pdf.

Fieseler, Ch., Lutz, Ch., \& Meckel, M. (2015). An inquiry into the transformation of the PR roles' concept. Corporate Communications: An International Journal, 20(1), 76-89.

Fleishman Hillard. (2019). Public affairs and government relations. Retrieved February 16, 2019, from https://fleishmanhillard.pl/\%C2\%A0doswiadczenie/public-affairs/.

Gifford, J. (2010). Digital public relations: e-marketing's big secret. Continuing Higher Education Review, 74, 62-72.

Godewski, A. (2011). Jak wybrać agencję PR? [How to choose a PR agency?]. In ZFPR (Eds.), Sztuka public relations. $Z$ doświadczeń polskich praktyków [The art of public relations. From the experience of Polish practitioners] (p. 341). Warszawa: Wydawnictwo Związek Firm Public Relations.

Olędzki, J., \& Tworzydło, D. (2009). Leksykon public relations [Lexicon of public relations]. Rzeszów: Wydawnictwo Newsline and Bonus Liber.

Olędzki, J., Wojcik, K., Hope, E., \& Barlik, J. (2019). Profesjonalizm public relations w Polsce. Wstępne wnioski $z$ badania [Public relations professionalism in Poland. Preliminary conclusions from the survey]. Retrieved May 10, 2019, from https://kongresprofesjonalistow.pl/wp-content/ uploads/2015/04/wnioski_spo\%C5\%82ecznego_zespo\%C5\%82u_PR.pdf.

Patterson, J. (1999). Ethics still count. Vital Speeches, 65(23), 731.

The Princeton Review. (n.d.). A day in the life of a lobbyist. Retrieved May 10, 2019, from https://www. princetonreview.com/careers/88/lobbyist.

Przybysz, Ł. (2017). Raport PR bez komentarza - czyli stygmatyzacja medialna public relations [PR report without commentary - media stigmatization of public relations]. Warszawa: Wydział Dziennikarstwa, Informacji i Bibliologii Uniwersytetu Warszawskiego.

Thomlinson, J. (2016). Public relations as the new lobbyist rolodex. Journal of Professional Communication, 5(1), 135-180.

Tworzydło, D. (2017). Public relations praktycznie [Public relations in practice]. Rzeszów: Wydawnictwo Newsline.

Tworzydło, D. \& Szuba, P. (forthcoming). Rola profilaktyki antykryzysowej z perspektywy największych polskich przedsiębiorstw oraz agencji public relations na podstawie badań eksperckich [The role of anti-crisis prevention from the perspective of the largest Polish enterprises and public relations agencies on the basis of expert studies]. Marketing Instytucji Naukowych i Badawczych. 
Tworzydło, D., Szuba, P., \& Zajic, M. (2017). Analiza kondycji branży public relations [The analysis of the condition of the public relations industry]. Rzeszów: Wydawnictwo Newsline.

Zerfass, A., Verčič, D., \& Wiesenberg, M. (2016). The dawn of a new golden age for media relations? How PR professionals interact with the mass media and use new collaboration practices. Public Relations Review, 42(4), 499-508.

Związek Firm Public Relations. (2019). Cała Prawda o PR, czyli jak o PR mówią media [The whole truth about PR, or what the media say about PR]. Retrieved February 13, 2019, from http://www. prbezkomentarza.pl. 